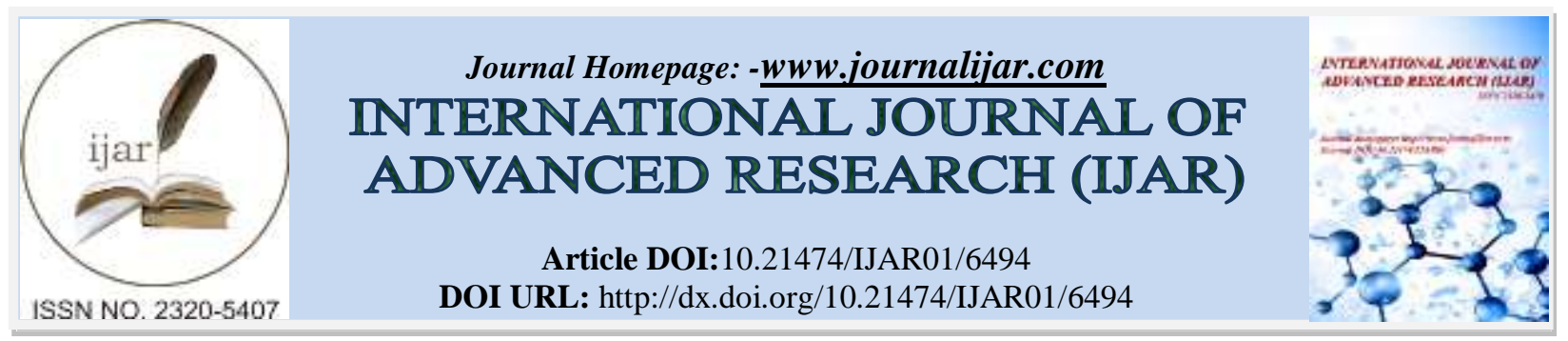

RESEARCH ARTICLE

\title{
FINANCIAL OPERATING PERFORMANCE AND CHALLENGES OF OMO AND WISDOM MICROFINANCE INSTITUTIONS IN DILLA TOWN, ETHIOPIA.
}

\author{
Dechasa Seifu Ashenafi. \\ Lecturer at wolaita Sodo University, College of Business and Economics, Department of Accounting and Finance. \\ P.O.BOX-138. Wolaita Sodo, Ethiopia.
}

\section{Manuscript Info}

Manuscript History

Received: 10 December 2017

Final Accepted: 12 January 2018

Published: February 2018

Keywords:-

Micro Finance, loan repayment performance, loan diversion, loan rationing, impact.

\begin{abstract}
Micro finance being practiced in many developing countries to address the low income society and thereby to improve their livelihood. Ethiopia is also one of the countries where microfinance has been given due consideration as a safety net for the poor to help them to overcome the adversities of poverty. This research aimed to study the financial operating performance and challenges of OMO and WISDOM microfinance institutions in Dilla town, Ethiopia The findings of this study revealed that Provide small business training to the clients, a high interest rate charged on loan, lack of skill of the clients on the fields (sectors), client marketing problems and the loan size given to the clients were too small were the main challenging areas hampering the performance of MFIs in Dilla Ethiopia. The study made recommendations which are aimed to enhancing the operating performance and solves challenges of OMO and WISDOM microfinance institutions.
\end{abstract}

\section{Introduction:-}

Micro-finance is one of the ways of building the capacities of the poor who are largely ignored by Commercial banks and other lending institution and graduating them to sustainable self employment activities by providing them financial services like credit, savings and insurance. The reasons of this neglect are many. Often, such credits are just not profitable enough for bank, because economies of scale. By focusing on small amounts, and easing collateral requirements, microfinance institution are better equipped to target poor individuals or groups who need resources to finance small scale investments. To provide micro-finance and other support services, MFIs should be able to sustain themselves for a long period (Anandet al.2011).

In Ethiopia, the potential demand for financial services, particularly micro-credit is huge. However, the existing supply of financial services to the poor is very limited. As a strategic tool in alleviating the problem, though provision of micro-finance services by government and non-government organizations were started in the past years, much emphasis was not given until the recent years.

Institutionalization of microfinance is evolved after the Ethiopian government issued the proclamation No.40/1996. Because $\mathrm{NGO}_{\mathrm{S}}$, government agencies and cooperatives and others perform microcredit delivery and savings 
mobilization in the country, in a scattered and inconsistent way, the government took the initiative to establish the regulatory framework in order to facilitate the sound development of the microfinance industry. This resulted in institutionalization of around $31 \mathrm{MFI}_{\mathrm{S}}$ which are currently operating in the country. All microfinance institutions has grown considerable in the last years and been able to extend their services thousands of poor customers.

All organization found in the world face some important and basic problems, which have to be assessed and identified for the better performance of the organizations objectives. Accordingly OMO MFI and WISDOM MFI are also such organizations which encounter such problems, from this point of view that the researcher was interested and decided to take the study and thereby the paper addressed such issues.

\section{Statement of the problem:-}

In countries like Ethiopia where majority of the population is poor, micro financing activities play significance role by lending money to the poor. Despite their contribution, there are many economic constraints limiting their activities as well as dynamism or improvement in their services. Recognizing the importance of $\mathrm{MFI}_{S}$, the governments' supports these institutions by giving legal entities and facilitating a working environment.

Following their establishment, the microfinance institutions have two-fold objectives; first, mobilizing the vast majority of the able poor capable of participating in the economic activity with little support from the institutions, and second, as formalized financial institutions, are expected to make profit for their continued existence. To achieve both objectives, the institution ought to work towards institutional sustainability. The simple increment of the number of the institutions and their capital alone or their better financial performance toward their narrow organizational objective may not speak about the success in achievement of the set national objectives. Rather the operation should be measured by indicators like the rate of increase in the coverage of needy population, the retaining rate of existing beneficiaries, diversification and expansion of funding sources, the quality of the service, financial performance, etc.

By observing its current resources and some other current situation we can mention some probable courses that give to these problems; lack of sufficient finance, poor loan management, low saving mobilization, materials ,etc. Furthermore, throughout their operation little effort is made to change, modify, and create new products in the industry.

And in this paper the study geared towards assessing whether the MFIs are financially and operationally sound or not, and to assess such variables (problems) mentioned above and other Challenges which are more frequent to OMO MFI and WISDOM MFI in Dilla town.

\section{Objectives of the study:- \\ General objective:-}

The main objective of the study is asses the financial operating performance and challenges of OMO and WISDOM microfinance institutions in Dilla town, Ethiopia

\section{Specific objectives:-}

The specific objectives of the paper include:-

1. To measure the rate of increase in the coverage of the beneficiaries (outreach).

2. To evaluate the participation of women in the service of the institution.

3. To compare the enterprises financial performance

4. To identify the challenges which are prevalent in the operation of $\mathrm{MFI}_{\mathrm{S}}$

\section{Review of Literature:-}

\section{Microfinance Institution (MFI):-}

Microfinance institution is institutions, which provide primary financial service for the low income group at fair interest rate. According to Welday (2000) "Microfinance institutions are institutions that provide suitable financial and other services using innovative methodologies systems at lower cost to the need of low income section of the population". Microfinance institution is often defined in terms of the following characteristics: Targeting the poor (especially poor women), Promoting small business, Building capacity of the poor, combining credit with savings charging commercial interest rate.(Dejene, 1998). 


\section{How to measure the performance of Microfinance programs:-}

The achievements of MFIs are examined through the lenses of standard industry performance metrics over a series of variables: Outreach (breadth and depth), financial structure, financial performance, efficiency and productivity, and portfolio quality (Lafourcade, et.al, April 2005, p. 6, as cited in Seyoum A, 2007). The achievement of MFI $I_{S}$ can be evaluated in terms of social performance and financial performance.

\section{Financial policies of the government of Ethiopia:-}

A number of policies have been designed to govern the financial sector and reflect the overall banking policies of the government and regulate the way banks and other financial institutions operate in Ethiopia. Proclamation No.40/1996 is directly related the microfinance promotion policy. The proclamation provides that micro financial institutions should be established as share companies, the capital of which is owned fully by Ethiopian, national and/or organization registered under the commercial code of 1960. As a result NGOs are apparently excluded from directly engaging in micro financing business. However, NGOs of domestic origin registered under the civil code, can be shareholders of micro-finance institutions.( Sani Mubarek, 2006).

The minimum capital required to establish a micro finance institution is birr two hundred thousand (about 24,000 US Dollar) unlike birr 75 million (10 million US Dollar) for formal banks. There has been a gradual move from long time fixed rate of interest to market rate. The directives that issued by NBE in May 2002 has removed partly the Br. 5000 single borrower limit to MFIs which mobilized Br.1,000,000 birr of savings and also raised the loan repayment period from one year to two years for all MFIs. The minimum interest rate that shall be paid per annum by MFIs on savings and time deposits has been reduced to 3 percent.(Sani Mubarek, 2006).

\section{Empirical literature review:-}

B.Befikadu (2007) evaluates the outreach and financial performance of Ethiopian microfinance institutions. From the outreach angle, the study identified that while MFIs reach the very poor, their reach to the disadvantages particularly to women is limited. From financial sustainability angle, He found that MFIs in Ethiopia are hopeful (profitable).

Similarly, Sani Mubarek (2006) examines the sustainability of Ethiopian Microfinance institutions. He found that both outreach and financial self-sustainability are positively interrelated. Institutional sustainability is a key element in achieving outreach and financial sustainability.

Seyoum (2007) assesses the challenges and Financial and Operating performances of MFIs in Addis Ababa. In the study he suggests that to enhance loan disbursement the institutions should do their level best to minimize the dropout rates and increase outreach.

Various studies on different countries on the performance of the MFIs confirm this Cited in B.Befekadu Kereta.(2007). For example, in Bangladesh a microfinance institution called Grameen Bank at the end of 2000 reported 2.4 million members, where 95 percent of them are women, with \$225 million outstanding loan. In addition, Thailand also has reported impressive outreach about 70 to 80 percent through agricultural lending by the Bank for Agriculture and Agricultural Cooperative (Meyer, 2002). In general, a lot number of microfinance institutions have registered impressive outreach in several developing economies including India, Cambodia, and others.(Meyer, 2002).

A survey by Robert cull and others on the performance of leading MFIs in 49 countries finds interesting results. It founds over half of surveyed MFIs are profitable after making adjustment of subsides.

\section{Research Design:-}

In order to achieve the objectives of the research, data interrelated to the micro-finance of the institutions were compiled from secondary data source and from primary sources. Hence this research adopted mixed design.

\section{Target population:-}

There are 31 microfinance institutions currently exist in countrywide. Among them 3 microfinance institutions are found in Dilla town. The study focused its survey on this locality/ area/. From the three microfinance institutions two of them are selected, because of LETTA MFI is one of the newly emerged institution which is found in Dilla town, as it is infant stage, enough data are not available. Therefore, the researcher decided to study the $2 \mathrm{MFI}_{\mathrm{S}}$ with 
purposive sampling method. And due to a large number of clients exist in the $2 \mathrm{MFI}_{S}$, the paper forced to use microenterprises' clients as a respondent of the study. Thereby, some of the institutions' officials and microenterprises' clients have been considered as a subject of the study with stratified random sampling technique.

\section{Data collection Methods and instruments:-}

The study was designed both primary and secondary data collection techniques. Review of annual reports, financial statements, and other relevant documents of the $\mathrm{MFI}_{\mathrm{s}}$ have been used as the sources for the secondary data collection.

Both structured and unstructured questionnaires have been developed as instruments of primary data collection tools so as to get the necessary information from the top officials of the institutions, and the beneficiaries'/clients/.

\section{Data Analysis tools used:-}

Based on the general concepts, the statement of the purpose of the institutions' existence, and their real practice; strength and gaps can be identified and analyzed using qualitative and qualitative analysis. That is, ratio analyses, comparative analysis of financial statements over time (trend analysis), descriptive presentations on responses of beneficiaries are including as part of quantitative analysis. Under qualitative analysis assessment of the institutions operation were analyzed based on the officials' response and the secondary data collected from the document.

Analysis and interpretation of data:-

Table 1:-Clients and Officials response on the participation of women in the MFIs

\begin{tabular}{|c|c|c|c|c|c|c|c|c|}
\hline & \multicolumn{2}{|c|}{ Wisdom } & \multicolumn{2}{|l|}{ Omo } & \multicolumn{2}{|l|}{ Total } & \multicolumn{2}{|l|}{ Percent } \\
\hline $\begin{array}{l}\text { 1. How do you rate the } \\
\text { participation of women in } \\
\text { the MFIs? }\end{array}$ & Clients & Officials & Clients & Officials & Clients & Officials & Clients & Officials \\
\hline A. Very High & 51 & 4 & 11 & 3 & 62 & 7 & $37.35 \%$ & $58.33 \%$ \\
\hline B. High & 13 & 1 & 32 & 2 & 45 & 3 & $27.11 \%$ & $25 \%$ \\
\hline C. Fair (Average) & - & - & 41 & 2 & 41 & 2 & $24.7 \%$ & $16.67 \%$ \\
\hline D. Low & - & - & 18 & - & 18 & - & $10.84 \%$ & - \\
\hline E. Very low & - & - & - & - & - & - & - & - \\
\hline $\begin{array}{l}\text { 2. Do you know someone who } \\
\text { showed improvements in } \\
\text { his/her life or business } \\
\text { because of the service } \\
\text { she/he obtained from the } \\
\text { MFIs? }\end{array}$ & & & & & & & & \\
\hline A. I know many & 22 & & 31 & & 53 & & $31.93 \%$ & \\
\hline B. I know very few & 38 & & 63 & & 102 & & $61.45 \%$ & \\
\hline C. Do not know anyone & 4 & & 8 & & 11 & & $6.63 \%$ & \\
\hline
\end{tabular}

Source: Dilla Micro Finance Survey, May 2015

MF clients and officials were also asked to rate the participation of women in the MFIs. Hence, $62(37.35 \%)$ of the clients and 7 (58.33\%) of the officials' rated women participation as "very high". Another $45(27.11 \%)$ of the clients and $3(25 \%)$ of the officials rated women participation as "high". While some $41(24.7 \%)$ of the clients and 2 $(16.67 \%)$ of the officials rated women participation as "Average". The rest $18(10.84 \%)$ of the clients rated women participation as "Low". However, the operations reports obtained from the MFIs revealed that women clients constituted from $33 \%$ (for Omo MFI) to $68 \%$ (for Wisdom) of the total clients. Thus, though most clients and officials rated women clients' participation as "high" and "very high", the reports obtained from the institutions disclosed that the participation of women should be rated as "Low "for Omo MFI and high for Wisdom MFI. Clients of MFIs were also asked whether or not they know someone who showed improvements in his/her life or business because of the services of the MFIs. Accordingly, the majority 102 (61.45\%) of them replied that they know very few individuals who made a change in their life or business activities. Another 53 (31.93\%) of the clients responded that they know many people who made a change in their life and business activities due to the services of the MFIs. The rest $11(6.63 \%)$ of the clients do not know anyone who made a change in life or business because of the services 
of the MFIs. Thus, from the above responses one can infer that only limited numbers of individuals had change in life and business activities as a result of the services of the $\mathrm{MFI}_{\mathrm{S}}$.

Table 2:-Adequacy of Loan Size and Repayment Period

\begin{tabular}{|c|c|c|c|c|}
\hline & Wisdom & Omo & Total & Percent \\
\hline \multicolumn{5}{|l|}{$\begin{array}{l}\text { 1. How do you evaluate } \\
\text { the loan size? }\end{array}$} \\
\hline A. Average(fair) & 11 & 19 & 30 & $18.07 \%$ \\
\hline B. Low & 15 & 48 & 63 & $37.95 \%$ \\
\hline C. Very low & 38 & 35 & 73 & $43.97 \%$ \\
\hline D. High & - & - & - & - \\
\hline E. Very High & - & - & - & - \\
\hline \multicolumn{5}{|l|}{$\begin{array}{l}\text { 2. Does the loan size } \\
\text { shows: }\end{array}$} \\
\hline A. Increasing trend & 51 & 77 & 128 & $77.11 \%$ \\
\hline B. Decreasing trend & - & - & - & - \\
\hline C. No change & 5 & 9 & 14 & $8.43 \%$ \\
\hline D. Do not know & 8 & 16 & 24 & $14.46 \%$ \\
\hline \multicolumn{5}{|l|}{$\begin{array}{l}\text { 3. How do you rate the } \\
\text { loan repayment rate? }\end{array}$} \\
\hline A. Sufficient & 28 & 39 & 67 & $40.36 \%$ \\
\hline B. Very Short & 36 & 63 & 99 & $59.64 \%$ \\
\hline C. Very Long & - & - & - & - \\
\hline
\end{tabular}

Source: Dilla Micro Finance Survey, May 2015.

MF clients were asked to express their ideas about the adequacy of the loan size. Accordingly, the majority 73 $(43.97 \%)$ of the clients responded the loan size is "very low". 63 (37.95\%) of them believe that the loan size is "low". The rest $30(18.07 \%)$ of the clients rated the loan size as "average". Thus, from this one can conclude that the loan size that MFIs extend to clients is very low.

A question was also forwarded to MF clients to express their views whether or not the loan size trend is increasing. Thus, a great majority $128(77.11 \%)$ of the MF clients replied that the loan size shows increasing trend. While 14 $(8.43 \%)$ of them respond no change. Another $24(14.46 \%)$ of the clients failed to respond to the item. Hence, it is evident that for those clients who make successful repayment of loan, the next loan size will be increased.

Regarding the loan repayment period, 99 (59.64\%) of the clients responded that the loan repayment period is "Very short". The rest $67(40.36 \%)$ of the clients replied that the loan repayment period as "sufficient". Thus one can infer that the repayment period that MFI extend to clients is very short.

\section{Mechanisms Used to Select Borrowers:-}

Officials in the selected MFIs were asked how the client obtains the legitimacy necessary to enable him/her to borrow. Accordingly all $12(100 \%)$ of the officials responded that the client must present a document certifying his/her degree of poverty and must present a government employee with above a certain monthly salary as a collateral.

\section{Products/Services of MFIs:-}

The types of financial products/services that the MFIs currently offered according to the officials in the selected MFIs are micro credit (loan) and savings (both compulsory and voluntary).

Concerning the loan policy of the MFIs, the clients in the institutions were asked. Hence, $86(51.81 \%)$ of the clients responded that the current loan size and the repayment period needs to be improved (increased). Another 42 (25.30 $\%)$ replied that no problem on the repayment period but the loan size need to be improved. The rest $38(22.89 \%)$ of the clients responded that no problem on the current loan size but the repayment period need to be improved. Thus 
one can note that from the response of the clients, the current loan size of the $\mathrm{MFI}_{\mathrm{S}}$ is too small with short repayment period, therefore, it need to be improved.

Regarding the incentive mechanisms that the institutions currently used to encourage early payment of loan by clients, $89(53.61 \%)$ of the clients responded that increase the loan size and the rest $77(46.38 \%)$ replied that extending the credit period.

Accordingly, all the MF officials responded at the same time that increasing the loan size and extending the credit period further in the next loan. Thus, one can infer that the incentive mechanisms that the $\mathrm{MFI}_{\mathrm{S}}$ currently used to encourage early payment of loan by clients are increasing the loan size for those who make timely repayments and extending the credit periods further in the next loan.

Table 3:-Views on the Challenges of the Current Operations of MFIs

\begin{tabular}{|l|c|c|}
\hline Response & MF clients N = 166 & MF officials N=12 \\
\hline $\begin{array}{l}\text { Lack of knowledge and experience on the } \\
\text { part of the society }\end{array}$ & $7(4.22 \%)$ & $6(50 \%)$ \\
\hline Too small loan size & $54(32.53 \%)$ & $5(41.67 \%)$ \\
\hline High interest rate on loan & $74(44.58 \%)$ & - \\
\hline Lack of skill of the clients on the fields & - & $5(41.67 \%)$ \\
\hline $\begin{array}{l}\text { Clients marketing problems (i.e., very low market for } \\
\text { their products, not having sufficient working place for } \\
\text { customers, etc) }\end{array}$ & $22(13.25 \%)$ & $3(25 \%)$ \\
\hline Shortage of loan able funds & - & $2(16.67 \%)$ \\
\hline Inadequate training to clients & $31(18.67 \%)$ & - \\
\hline Takes very long time to process loan & $15(9.04 \%)$ & - \\
\hline $\begin{array}{l}\text { Cultural barrier in the rural areas (i.e., hidden women to } \\
\text { come out to the forefront) }\end{array}$ & $8(4.82 \%)$ & $7(58.33 \%)$ \\
\hline Bad weather condition (on the repayment of loan) & - & $6(50 \%)$ \\
\hline Source Dill Min Fon
\end{tabular}

Source: Dilla Micro Finance Survey, May 2015.

As can be seen from the above table, 7 (4.22\%) of MF clients and $6(50 \%)$ of the officials disclosed that the major challenges of the current operations of MFIs is lack of knowledge and experience on the part of the society. They express that most clients do not have sufficient knowledge toward MF loan, they considered as a donation, this will create a problem on the repayment.

$54(32.53 \%)$ of the clients and $5(41.67 \%)$ of the officials in the MFIs believed that a very small loan size of the MFIs is a major challenge in the current operations of MFIs. Whereas 5 (41.67\%) and $2(16.67 \%)$ of the officials in the MFIs disclosed that the major challenges in the current operations of MFIs are lack of know how (skill) of the clients on the fields and shortage of loan able funds, respectively.

On the other hand, the majority 74 (44.58\%) of the clients in the MFIs strongly believed that the major challenge is the high interest rates charged on loans by the MFIs. They express that due to a high interest rate charged on loans many clients forced to quite relationship with their respective MFIs.

Another group of clients $22(13.25 \%)$ and 3 (25\%) officials mentioned that clients marketing problems is considered as a major problem in the operation of MFIs. They express that there is no or low demand for their products/services. $31(18.67 \%)$ and $15(9.04 \%)$ of the clients replied that inadequate training to clients and long loan processing time are major constraints in the current operation of MFIs.

On the other hand, $6(50 \%)$ of the officials mentioned that bad weather condition is the major challenge in the operation of MFIs. The rest 8 (4.82\%) of the clients and 7 (58.33\%) of the official replied that cultural barrier is the major constraints in the current operation of MFIs. They express that women are hinders to come to the forefront in the rural areas, this will create a problem in reaching the target clients. 
Thus, the responses obtained from the clients and officials of MFIs indicated that high interest rate charged on loan, small loan size, client marketing problems and lack of knowhow of the clients on the fields, cultural barrier are the major challenges facing the current operations of MFIs.

Table 4:-Measures to be taken to Improve MFI operation

\begin{tabular}{|l|c|c|}
\hline \multicolumn{1}{|c|}{ Response } & MF clients N= 166 & MF officials N=12 \\
\hline $\begin{array}{l}\text { MFIs should extend other financial services like micro } \\
\text { insurance, local money transfer, etc }\end{array}$ & $8(4.82 \%)$ & $5(41.67 \%)$ \\
\hline $\begin{array}{l}\text { MFIs should increase the loan size and extend } \\
\text { further the loan repayment period }\end{array}$ & $84(50.60 \%)$ & - \\
\hline Continuous training and follow up of clients must be made & $33(19.89 \%)$ & $4(33.33 \%)$ \\
\hline $\begin{array}{l}\text { MFIs in coordination with the government and other } \\
\text { institutions should solve the marketing problems of the } \\
\text { clients }\end{array}$ & $23(13.85 \%)$ & $25 \%)$ \\
\hline Reduction of MF loan interest rate & $99(59.64 \%)$ & $3(25 \%)$ \\
\hline $\begin{array}{l}\text { MFI must use new technologies to facilitate the service } \\
\text { offered to the clients }\end{array}$ & $34(20.48 \%)$ & $5(41.67 \%)$ \\
\hline $\begin{array}{l}\text { NBE should lift the loan limit that MFIs can extend large } \\
\text { loans and shortage can be resolved }\end{array}$ & - & $37 \%)$ \\
\hline $\begin{array}{l}\text { MFIs should create awareness among the societies toward } \\
\text { the financial service offered by the institution }\end{array}$ & $11(6.23 \%)$ & \\
\hline
\end{tabular}

Source: Dilla Micro Finance Survey, May 2015.

Regarding the measures to be taken to improve MF operations, 8 (4,82\%) of the clients and 5 (41.67\%) of the officials said that to provide efficient services MFIs should extend other financial service like micro insurance, local money transfer etc. to diversify their revenue source.

Whereas, the majority 99 (59.64\%) of the clients responded that reduction of MF loan interest rate should be made to reduce the dropout rates and to attract more clients.

On the other hand, 3 (25\%) of the officials in institutions suggested that NBE should lift the loan limit that MFIs can extend to their clients.

The majority $85(50.60 \%)$ of the clients said that MFIs should increase the loan size and the loan repayment period to improve their service. And $23(13.85 \%)$ of the clients and $3(25 \%)$ of the officials contended that MFIs in coordination with the government and other institutions should solve the marketing problems of the clients.

$33(19.89 \%)$ of the clients and $4(33.33 \%)$ of the MFIs officials suggested that to provide efficient and effective service continuous training and follow up of clients should be conducted.

A significant number $34(20.48 \%)$ of the clients suggested that to improve the services that MFIs provide, they must use new technologies. Another $11(6.23 \%)$ of the clients and $4(33.33 \%)$ of the MFIs officials suggested that to provide efficient and effective services, MFIs should create awareness among the societies (target clients) toward the financial service offered.

Table 5:-Credit Operations

\begin{tabular}{|c|c|c|c|c|c|c|c|c|}
\hline & \multicolumn{4}{|l|}{ WISDOM } & \multicolumn{4}{|l|}{ OMO } \\
\hline & 2013 & 2014 & $\begin{array}{l}\text { Project } \\
2014\end{array}$ & $\begin{array}{l}\text { Actual } \\
\%\end{array}$ & 2013 & 2014 & $\begin{array}{l}\text { Project } \\
2014\end{array}$ & $\begin{array}{l}\text { Actual } \\
\%\end{array}$ \\
\hline $\begin{array}{l}\text { Total loans } \\
\text { disbursed }\end{array}$ & $1,870,000$ & $6,819,910$ & $3,468,525$ & 197 & $3,889,654$ & - & $3,092,639$ & 0.00 \\
\hline $\begin{array}{l}\text { Loan } \\
\text { collection }\end{array}$ & 992,722 & $2,776,100$ & $2,234,263$ & 124.25 & $1,140,614$ & - & $2,192,185$ & 0.00 \\
\hline $\begin{array}{l}\text { Outstanding } \\
\text { loan }\end{array}$ & 877,278 & $4,043,810$ & N/A & - & $2,749,040$ & - & 900,454 & 0.00 \\
\hline
\end{tabular}


N.A Not Available - Source: Dilla Micro Finance Survey, May 2015.

\section{Loans disbursement:-}

In the year 2013 Omo MFI planned to disbursed birr 3,092,639. However, the institution do not disburse the loan entirely in the year. Which unable the firm to achieve its plan by $100 \%$. According to the Sub-branch manager response, the reason for this no achievement were due to a higher amount of loan arrears (birr 4,105,061) reported at the end of 2013.

On the other hand, during 2014 Wisdom MFI planned to disburse a total of birr 3,468,525 but actually disbursed birr $6,819,910$, which enabled the firm to achieve $197 \%$ of its plan. It is higher than the planned amount by $97 \%$. It seems that due to a good outreach program by the firm.

\section{Loan collection:-}

During 2014 Omo MFI planned to achieve a collection of birr 2,192,185. However, due to no actual disbursement during the year, the institution not achieved its plan entirely.

Considering the Wisdom case, in 2014 it planned to collect birr 2,234,263, but actually collected birr 2,776,100, which enabled the firm to achieved $124.25 \%$ of its plan. The higher level achievement in collection seems that high level of disbursement and good follow-up of clients during the year.

\section{Outstanding Loan:-}

In 2014 Omo MFI was planned that outstanding loan at the end of the year would reach a total of birr 900,454. However, due to no loan disbursement during the year, the institution does not achieve its plan by $100 \%$.

On the other hand, at the end of 2014 Wisdom MFI the actual reported birr 4,043,810 was outstanding loan. As compared to the last year it exceeds by $361 \%$. This high outstanding loan is due to high level of disbursement and lower level of collection made during the year.

\section{Portfolio at risk (Quality):-}

The occurrence of arrears has its own implications on the level of risks. Therefore, it is essential to assess the risks associated with the contamination of the part of the outstanding loans due to the arrears. All the outstanding loans with 30 and more days with arrears are considered in the assessment of the portfolio at risks according to the industry norms and standards.

In the year 2013 Omo MFI reported birr 32,344 as arrears. Compare to the total outstanding loan balance for the same year, its portfolio at risk is $26.64 \%$, it is quite larger than the target set by the institution (8\%). The higher portfolio at risk reported for Omo MFI at the end of 2013 is indicative of less follow-up activities made to the clients, which leads to bankruptcy of clients.

For Wisdom MFI the actual arrears reported at the end of 2013 was birr 53,149. Compared to the total outstanding loan balance for the same year, it is $6.05 \%$, which is below the target set by the institution (7\%). However, in 2014, the portfolio at risk ratio indicate that $11.62 \%$ (with arrears of birr 470,203 ), which is slightly larger than the plan (7\%). The lower the portfolio at risk reported at the end of 2013 is indicative of adequate follow-up activities made to the clients.

Regarding the loan loss ratio (Write-off), Wisdom MFI reported 1.52\% and 0.32\% loan loss ratios in 2013 and 2014 fiscal years, respectively. Compared to the industry standard (norm) of $2 \%$, these ratios are reported well because of within the industry standard.

Table 6:- Performance Ratios Analysis

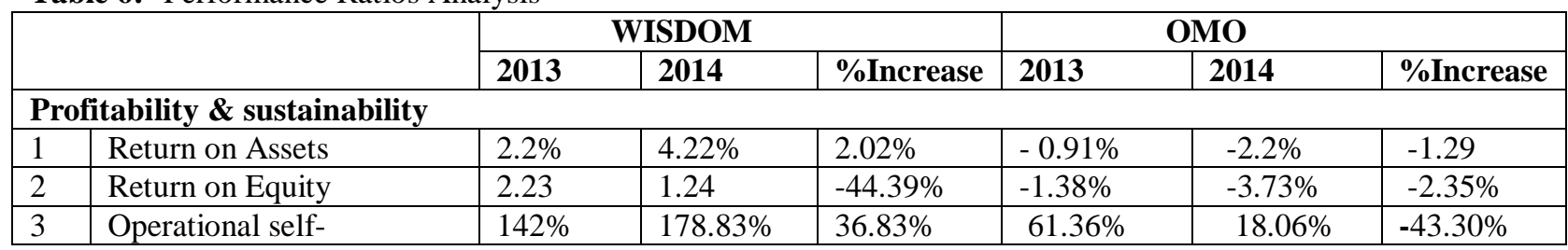




\begin{tabular}{|c|c|c|c|c|c|c|c|}
\hline & sufficiency & & & & & & \\
\hline 4 & Financial sustainability & $119.87 \%$ & $156.14 \%$ & $36.27 \%$ & $61.36 \%$ & $18 \%$ & $-43.36 \%$ \\
\hline \multicolumn{8}{|c|}{ Efficiency and productivity } \\
\hline 5 & Operating Cost Ratio & $18 \%$ & $9.2 \%$ & $8.80 \%$ & $8.25 \%$ & - & - \\
\hline 6 & $\begin{array}{l}\text { Cost per Active } \\
\text { client(Borrowers) }\end{array}$ & Br.556 & Br.687.91 & $-23.76 \%$ & Br.805.07 & - & - \\
\hline 7 & $\begin{array}{l}\text { Borrowers per credit } \\
\text { Officers (Loan officer } \\
\text { productivity) }\end{array}$ & 71 & 135 & $90.14 \%$ & 94 & - & - \\
\hline \multicolumn{8}{|c|}{ Asset/Liability Management } \\
\hline 8 & Debt to Equity Ratio & 98.10 & 28.40 & $71.05 \%$ & $51 \%$ & $68.90 \%$ & $17.90 \%$ \\
\hline 9 & Liquidity Ratio & 1.02 & 0.56 & $-45.10 \%$ & 2.89 & 2.33 & $-19.38 \%$ \\
\hline 10 & Current Ratio & 3.93 & 3.70 & $-5.85 \%$ & 2.90 & 2.38 & $-17.93 \%$ \\
\hline \multicolumn{8}{|c|}{ Portfolio Quality } \\
\hline 11 & $\begin{array}{l}\text { Portfolio -At-Risk (PAR) } \\
\text { Ratio > 30days }\end{array}$ & $6.05 \%$ & $11.62 \%$ & $-5.57 \%$ & $26.64 \%$ & - & - \\
\hline 12 & Write-offs Ratio & $1.52 \%$ & $0.32 \%$ & $1.2 \%$ & N.A & N.A & - \\
\hline
\end{tabular}

N.A Not Available - Source: researcher's own computation from financial statements

\section{Financial Statements Analysis:-}

A careful analysis of financial statements can help decision makers to evaluate an organizations past performance and predicts its future performance. Such evaluations help managers, investors and others, and informed financial decisions.

Therefore, in line with this financial statement the respective $\mathrm{MFI}_{\mathrm{s}}$ are analyzed to show how well they are performing.

\section{Profitability Ratio:-}

\section{Return on assets:-}

Return on assets indicates how well a MFI is managing its assets (use of funds) to optimize its profitability. Return on assets should be positive. It provides an indication of the ability of a MFI to expand profitably with unsubsidized funding. If a $\mathrm{MFI}_{\mathrm{s}}$ registered a negative return on assets it indicates that there were not in managing their assets to optimize profit.

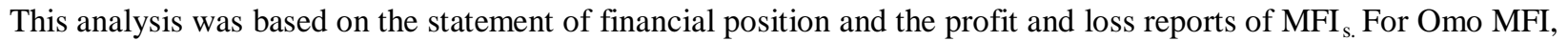
the total assets and the net worth at the end of 2014 decreased compared to the previous year, whereas the firm's total liabilities during the year showed increasing pattern. The decrease in assets and net worth are attributed to the higher operating losses suffered by the firm and thus, the Return on Assets and the Return on equity declined for the years 2013 and 2014 with the ratios of $-0.91 \%$ and $-2.2 \%$ for the return on Assets, respectively The negative ROA ratios are as a result of the net loss suffered by the firm in 2013 and 2014.

The return on assets (ROA) for Wisdom MFI for 2013 and 2014 fiscal years were 2.2\% and 4.22\%, respectively. The return on assets reported in the two years was very high compared to the Omo MFI. These high returns on asset ratios are mainly due to the high level of operating income reported by the firm. Thus, this tells the firm accomplished better performance compared to Omo MFI.

\section{Return on equity:-}

The Return on equity shows that the institution's ability to generate income from their core financial service activity. It should be positive.

For Omo MF the return on equity (ROE) measured based on its financial statement for the year 2013 and 2014 . The result revealed $-1.38 \%$ and $-3.73 \%$ in 2013 and 2014 , respectively.

The results for both years Show a negative ratios because of the increasing pattern of operating losses over the year. 


\section{Operational self- sufficiency:-}

This ratio shows the ability of the MFI to cover its total expenses from revenues or when the operating income is sufficient enough to cover operational cost like salaries, supplies, loan losses, and other administrative costs. An operating sustainability ratio exceeding $100 \%$ is indicative of $\mathrm{MFI}_{\mathrm{s}}$ sustainability.

For Omo MFI, the operational self-sufficiency, reported in the year 2013 and 2014 were $61.36 \%$ and $18.06 \%$, respectively. Thus, the results for both years indicated that the operating revenue is unable to cover its operating costs of the institution, because it is below the industry standard (100\%).

Whereas Wisdom MFI, reported in the same years were $142 \%$ and $178.83 \%$, respectively. Thus, from the report one can infer that the institution's operating income is sufficient enough to cover its operational cost. Similar pattern were reported for both institutions in the year 2013 and 2014 regarding the financial sustainability.

\section{Efficiency and productivity:-}

Operating expense /cost/ ratio:-

This ratio evaluates the operating cost ratio of the respective $\mathrm{MFI}_{S}$ by comparing their operating costs with the average value of loans outstanding. It is regularly assumed that the lower operating expense ratio, the higher the efficiency of an institution.

For Wisdom MFI the results showed 18\% and $9.20 \%$ for 2013 and 2014 fiscal years respectively. This ratio measures the cost per unit of money lent. Thus, the 2014 cost of $9.20 \%$ per unit of money lent is indicative of the better efficiency, as compared to the previous year.

When we look at the results of Omo, the year 2013 revealed 8.25\%. This ratio showed as compared to Wisdom MFI lower operating cost. Thus, the institution seems efficient.

\section{Productivity Ratio:-}

Number of active borrowers per credit officer:-

Regarding the productivity ratio, the total number of active borrowers for each of the respective $\mathrm{MFI}_{\mathrm{S}}$ was compared with the total number of loan officers.

Accordingly, for 2014 Wisdom MF the results obtained from its annual operations report indicated (541/4), or 135. Hence, compared to the 2013 report (284/4), or 71, the number increased significantly. Thus, this is evidencing that the firm's productivity.

Whereas the report obtained for Omo MF in 2013 showed (282/3), or 94, which is more productive, as compared to Wisdom in 2013.

\section{Cost per borrower:-}

It indicates an institution how much it currently spends in personnel and administrative expenses to serve a single borrower, it informs the MFI how much it must earn from each borrower to be profitable.

For Wisdom MFI, which incurred birr 556 and birr 687.91 to serve a single borrower in 2013 and 2014 respectively. Thus, one can infer that the institution is inefficient in the year 2014. Similar pattern to Omo MFI, which incurred birr 805.07 in 2013.

\section{Asset/Liability Management:- Liquidity and Current ratio:-}

Hence, the results for current ratio for Omo MFI indicated 2.9 and 2.38 for 2013 and 2014 fiscal years, respectively. From this one can note that the institution is able to meet its maturity (current) obligation.

With regard to liquidity ratio, Omo showed 2.89 and 2.33 for 2013 and 2014, respectively. The industry norm dictates companies in the industry to maintain liquidity ratio of greater than 1 (one). Thus, the institution able to meet its current obligation. 
However, for Wisdom MFI the analysis revealed a liquidity ratio of 1.02 and 0.56 for 2011 and 2014 fiscal periods, respectively. The ratio in 2014, which is a bit lower than what the industry standard dictates for similar firms.

With regard to current ratio for Wisdom, the analysis revealed a current ratio of 3.93 and 3.70 for 2013 and 2014 , respectively. Thus, one can infer that the institution is at a better position and be able to meet its entire current obligation without being engaged itself in borrowing.

\section{Financial strength:- \\ Debt to equity ratio:-}

Debt to equity ratio indicates how well the MFI is able to leverage (borrow funds to increase assets and thereby increase revenue and net profit) its equity to increase assets through borrowing. And measures the $\mathrm{MFI}_{\mathrm{S}}$ financial strength by comparing the total liabilities with the firms total equity for the same years.

Hence, the results for Wisdom MFI revealed 98.10 and 28.40 for 2013 and 2014, respectively. Thus, this reduction implying that the firm is financially strong and viable.

The financial strength of Omo MFI is also tested for 2013 and 2014. Accordingly, in 2013 the firm reported a ratio of $51 \%$ while in 2014 it is increased to $68.90 \%$. Thus, this implying that the firm not financially strong and viable. Some of the standards mentioned above taken from secondary source.(Sani. M , 2006) and (Seyoum.A, 2007).

\section{Conclusions:-}

1. The financial and operations reports of the selected MFIs were referred. Accordingly, the researcher found out that these reports were prepared in line with the accepted accounting standards.

2. From the analysis it has been concluded that females' participation in the services of Omo MFI is rated as low, whereas for Wisdom MFI rated as high. Thus, the inadequate and insufficient participation of female clients themselves in the design of the programs affects the level of poverty reduction.

3. It is indicated in the study that the number of active clients in the selected $\mathrm{MFI}_{\mathrm{S}}$ has shown increasing trend. Thus, client outreach activities of the institutions are performing well and are efficient.

4. The type and quality of products/services offered to clients affects the firm's ability to satisfy its clients. In this regard, the small loan size and short repayment period of the MFIs along with the high interest charge discourage clients. As a result of this, there is high client drop out and low client retention rates.

5. It is fact that the main source of revenue for MFIs is the revenue from loans. For the institutions to earn sufficient income it has to disburse loans in sufficient amounts. However, Omo MFI seems inefficient in meeting its target. Whereas Wisdom MFI reported a remarkable result, which is disbursed over its plan.

6. For any MFIs in order to function smoothly, it has to collect in sufficient amounts and on time the disbursed loans from the clients. As a result, it is indicated in the study that Wisdom MFI achieved over its plan. Thus, this is a good indication of the institution's efficiency and adequate follow-up activities.

7. The ROA and ROE for Omo MFI shows unfavorable results, for both 2013 and 2014 reflected a negative ratio. On the other hand, the ROA and ROE for Wisdom shows a positive ratio. Thus, the declining (negative) profitability ratios are the results of a huge net loss realized by the firm.

8. In terms of operating cost ratios both institutions shows declining ratios. Thus it has been concluded that the institutions shows their efficiency.

9. With regard to arrears Omo MFI reported relatively higher portfolio at risk ratio compare to its plan. This is due to the inadequate follow-up activities of the credit officers on the clients. On the other hand, Wisdom reported relatively lower portfolio at risk in 2013 compared to its plan. Thus, this is indicative of a high portfolio quality registered by the firm.

10. The result of the study revealed that Wisdom MFI already achieved its operational and financial self-sufficient. Whereas Omo not achieved the level of operational self-sufficient and not financially sustainable.

\section{Recommendations:-}

From the study it has been point out that the potential demand of the poor for micro credit is enormous. Therefore, the institutions should search enough amount of capital from both internal and external sources, besides to this the available money has to be distributed in such a way that gives priority for those most poor people of the nation. 


\section{Expand the scope of Small business training:-}

It is indicated in the findings that MFIs provide/offer small business training to the clients. However, the training is confined to only business training. Thus, MFIs should expand their scope of training to include bookkeeping and cost calculation, budgeting, and leadership/decision-making, etc.

\section{Enhance Women Participation:-}

The data obtained from the operations report of the MFIs show that women's participation in the services of Omo rated as low and for Wisdom rated as high. Thus, it is recommended that MFI $S$ should better focus on the female clients. Women's are specifically targeted because they make up the majority of the poor and are responsible for the social and economies of the family.

\section{Increase loan size \& repayment period:-}

It is asserted by the majority MFIs clients that the loan size given to the clients are too small with a short repayment period. It seems that small loan size and short repayment period along with the small returns from the use of the loan makes the MF Programmers inefficient. Thus, it is recommended that $\mathrm{MFI}_{\mathrm{S}}$ should further increase the loan size and extend the credit period.

\section{Expand financial services:-}

It is disclosed in the study that the type of services or products offered by MFIs are: loan (credit) and savings. However, MFIs should expand the scope of their services and extend services like micro insurance, local money transfer, etc.

\section{Empowering MFIs:-}

The results of the study shows that a high interest rate charged on loan by the MFIs, lack of skill of the clients on the fields (sectors), client marketing problems, are some of the problems facing the current operations of MFIs. Therefore, it is recommended that the micro and small enterprise should organize those clients who have skill (know how) on the fields. In addition, the $\mathrm{MFI}_{\mathrm{S}}$ together with other concerned bodies should solve the marketing problems of the clients and reduce the interest charged on loan.

\section{Target loan Disbursement:-}

With regard to loan disbursement it is indicated in the study that in 2014 Omo MFI do not achieved its plan entirely. The reason for no disbursement is due to a higher amount of loan arrears reported at the end of 2013. This higher loan arrears seems due to less follow-up activities of the clients by credit officers. Thus, it is recommended that the institution should do their level best to minimize the loan arrears to enhance loan disbursement. On the other hand, Wisdom MFI achieved 197\% of its plan efficiently. Thus, it is remarkable achievement as compared to Omo MFI.

\section{Measures must be taken to enhance the Profitability of Firms:-}

It is indicated in the study that Omo MFI reported a negative ROA and ROE ratios. The reason for this is due to a huge net loss realized during the periods. Thus, it is suggested that the institutions should do their best in order to cut some of the expenses and minimize the loan losses in order to be profitable.

\section{Improve the portfolio Quality:-}

The research study disclosed that Omo reported relatively higher arrears compared to the plan (target). The causes for these higher ratios seem the less follow-up of clients. Therefore, it is recommended that the institutions should conduct frequent follow-up activities on their clients. 


\section{References:-}

1. AnandRai and Dr.kanwal Anil.(2011).Financial performance of Microfinance institutions: Bank vs NBFC. New Delhi, India. Retrieved fromhttp://www.myresearchpie.com/ISSN: 2231-0703

2. B.Befekadu Kereta.(2007).Outreach and Financial Performance Analysis of Microfinance Institutions in Ethiopia. Ababa, Ethiopia.

3. Degene.A. and Ibrahim A.(1998)." Micro economic reforms in Ethiopia, since 1996, apaper to presented in the $8^{\text {th }}$ annual conference EEA"

4. Meyer, R. L. (2002)."Track Record of Financial Institutions in Assisting the Poor in Asia" ADB Institute Research Paper, No 49, December 2002.

5. Sani Mubarek Hussen .(2006).Sustainability of Ethiopian Microfinance Institutions ( The Case of Omo microfinance Institution (OMFI), Sidama microfinance institution (SMFI) and Addis Credit and Saving institution (AdCSI)

6. Seyoum Arega.(2007). Assessment of the Financial and Operating Performance and Challenges of $\mathrm{MFI}_{\mathrm{S}}$ in Addis Ababa A.A.U, Ethiopia.

7. Welday Amaha.(2000).Review of microfinance industry in Ethiopia, Regulatory frame work and performance occasional paper No.2,published by AEMFI, A.A, Ethiopia. 